\title{
Acute Suppurative Parotitis in Early Neonatal Period
}

\section{Erken Yenidoğan Döneminde Akut Süpüratif Parotit}

\author{
Mehmet Yekta Öncel', Onur Erişen², Meltem Koyuncu Arslan², Eda Karadağ Öncel ${ }^{3}$ \\ ${ }^{1}$ Department of Neonatology, Izmir Katip Celebi University School of Medicine, Izmir, Turkey \\ ${ }^{2}$ Clinic of Neonatology, Izmir Tepecik Training and Research Hospital, Izmir, Turkey \\ ${ }^{3}$ Clinic of Pediatric Infectious Diseases, Izmir Tepecik Training and Research Hospital, Izmir, Turkey
}

Cite this article as: Öncel MY, Erişen O, Koyuncu Arslan M, Karadağ Öncel E. Acute suppurative parotitis in early neonatal period. J Pediatr Inf 2019;13(1):e42-e44

\begin{abstract}
Acute neonatal suppurative parotitis (NSP) is a rare condition, characterized by parotid swelling and other local inflammatory signs. Common predisposing conditions include dehydration, Stensen's duct stasis, local trauma, immune suppression and prematurity. Staphylococcus aureus is the most common pathogen isolated from infants with NSP. Here, we present a case of unilateral suppurative parotitis successfully treated with ampicillin in a 7-day-old infant. In conclusion, acute NSP should be kept in mind in cases of swelling and tenderness in parotid gland during neonatal period.
\end{abstract}

Keywords: Neonatal suppurative parotitis, newborn, Stensen's duct

\section{Introduction}

Neonatal suppurative parotitis (NSP) is an infection of the parotid gland due to bacterial agents. The agent is often the Staphylococcus aureus $(1,2)$. Although it is rare in the neonatal period (0-1 month), its prevalence is 3.8/10.000 (1). Risk factors include dehydration, parotid channel obstruction, local trauma, immune suppression, and low birth weight $(2,3)$. Here we present a case of unilateral suppurative parotitis treated successfully in a 7-day-old infant.

\section{Öz}

Akut neonatal süpüratif parotit (NSP), parotiste şişlik ve lokal inflamatuvar belirtilerle karakterize nadir bir durumdur. Dehidratasyon, Stenson kanalında tıkanıklık, lokal travma, immünsüpresyon ve prematürite bilinen hazırlayıcı faktörlerdir. Staphylococcus aureus NSP'li bebeklerden izole edilen en yaygın patojendir. Burada yedi günlük bebekte başarılı bir şekilde ampisilin ile tedavi edilen tek taraflı süpüratif parotit olgusu sunulmuştur. Sonuç olarak, yenidoğan döneminde parotis bezinde şişlik ve hassasiyet ile başvuran olgularda akut NSP akılda tutulmalıdır.

Anahtar Kelimeler: Neonatal süpüratif parotit, yenidoğan, Stenson kanalı

\section{Case Report}

4145-gr male infant born by caesarean section from a forty-seven year-old mother at $40^{\text {th }}$ gestational week as $3^{\text {rd }}$ alive infant and $3^{\text {rd }}$ birth of the mother consulted to pediatric emergency service on the postnatal $7^{\text {th }}$ day because of unrest and swelling on the left side of his face. His medical history and family history were unremarkable. On physical examination, his body temperature was $37.5^{\circ} \mathrm{C}$ and there was approximately $5 \times 4 \mathrm{~cm}$ welling and tenderness on the left parotid

\footnotetext{
Correspondence Address / Yazışma Adresi

Mehmet Yekta Öncel

İzmir Katip Çelebi Üniversitesi Tıp Fakültesi,

Neonatoloji Bilim Dalı,

İzmir-Türkiye

E-mail:dryekta@gmail.com
}

Received: 18.10 .2018
OCopyright 2019 by Pediatric Infectious Diseases and Immunization Society. Available online at www.cocukenfeksiyon.org 


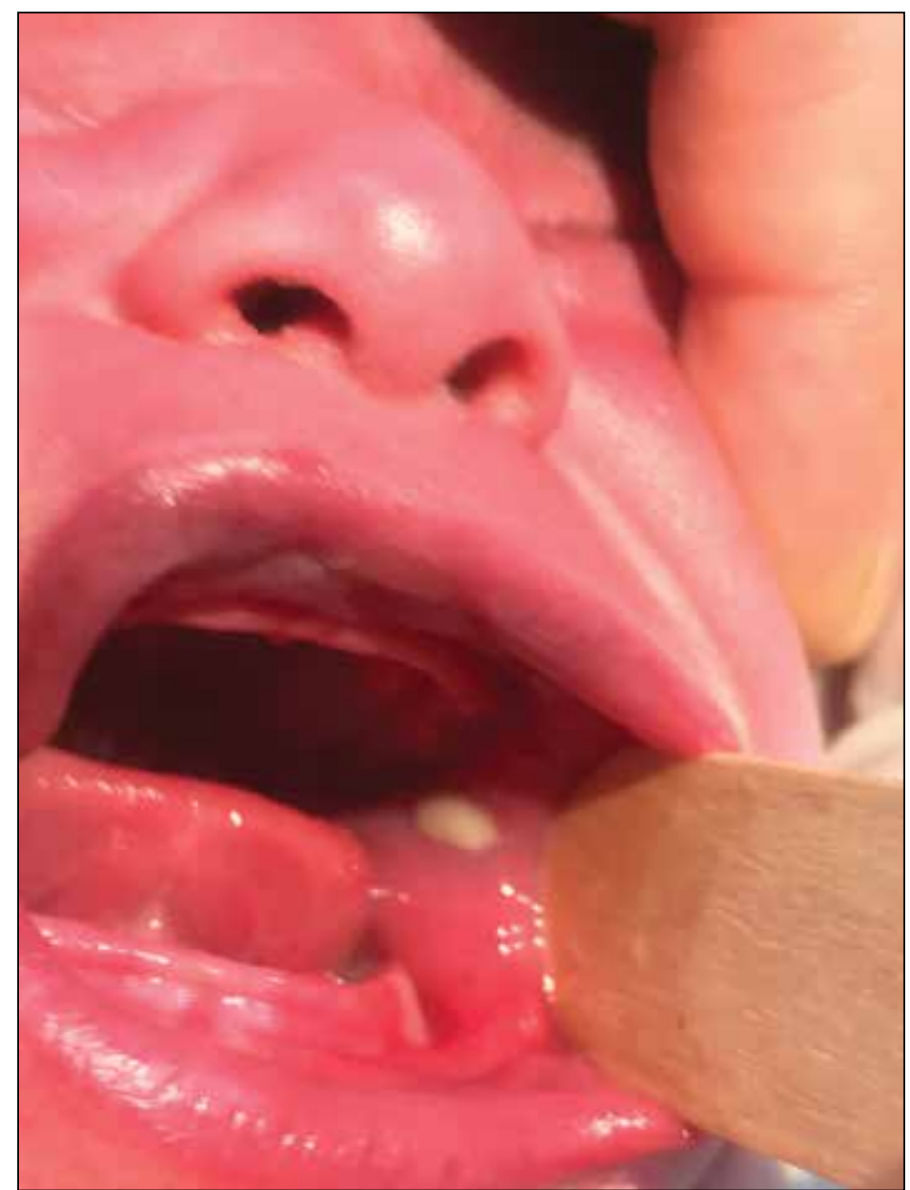

Figure 1. The purulent discharge from the left Stenson canal.

gland. The purulent discharge was observed coming from left Stenson canal in the mouth (Figure 1). At this point, pus culture was taken. According to the laboratory tests; white blood cell count was $16.000 / \mathrm{mm}^{3}$ (65\% neutrophil) and C-reactive protein (CRP) was 27.6 (0-5) mg/L. Renal and hepatic function tests, electrolytes, amylase and mumps serology were normal. The lymphocyte subgroups which were examined for immunosuppression were normal and anti-HIV was negative. On ultrasonography (USG), the deep lobe of the left parotid gland was found to be voluminous and heterogeneous. There was a $2 \times 1 \mathrm{~cm}$ lymphadenopathy in its neighborhood. In the case evaluated by the Otorhinolaryngology Department, sialectasis or obstruction in the parotid duct was not considered. The patient was evaluated as suppurative parotitis. After blood culture was taken, ampicillin treatment was started intravenously. In pus culture $S$. aureus reproduced while there was no reproduction in blood culture. S. aureus was susceptible to ampicillin in the anti-biogram. On the $2^{\text {nd }}$ day of the follow-up, the swelling in the parotid gland got smaller. The patient was discharged after 10 days of anti-biotherapy and his control examination was normal.

\section{Discussion}

The case meets the criteria for acute NSP diagnosis due to swelling in the parotid gland, purulent discharge from the Stenson canal and pathogenic bacterial reproduction in the pus culture. Acute suppurative parotitis is a very rare infection in the neonatal period. In the analysis conducted in 2012, 51 neonatal cases were reported in the literature (4).

Generally, patients present with unrest, crying and swelling with or without redness in the unilateral parotid region (5). Prematurity, low birth weight, male gender, dehydration, immune suppression, trauma, parotid channel obstruction can be listed among the risk factors (2-4). Especially more significant in premature babies, the reduction in saliva production, dehydration, sialectasia, ductility of the ductus such as stone or tumor cause the backflow through the parotid. Infection occurs by colonization of bacteria in the oral flora into the parotid canal $(3,4)$. Our case was a male infant with no history of prematurity or low birth weight. The patient had no history of hospitalization, oral trauma and immune suppression. No dehydration was observed at his admission to the hospital. Therefore, there was no risk factor other than male gender that would support suppurative parotitis in our case.

It is stated in the literature that laboratory markers are not specific in NSP. The number of white blood cells of $71 \%$ of cases was over $15.000 / \mathrm{mm}^{3}$ and neutrophil dominance was determined with peripheral smear (2). Serum amylase levels were generally not high. It is thought that this condition may be related to the immaturity of salivary isoenzyme activity in newborns (6). In our case as literature, leukocytosis and normal amylase levels with neutrophil dominance were detected. For NSP in newborns, S. aureus (55\%) is the most frequently isolated microorganism (2). Other frequently encountered agents are Streptococcus viridians, Streptococcus pyogenes, Escherichia coli and Fusobacterium nucleatum (2-4). Klebsiella pneumoniae and Pseudomonas aeruginosa have been reported in suppurative parotitis related to sepsis developing in hematogenous way $(7,8)$. In pus culture of our case, $S$. aureus reproduced while there was no reproduction in blood culture.

While antibiotic treatment is enough for $78 \%$ of NSP patients, there is usually no need for drainage. Clinical improvement occurs with a decrease in swelling of the parotid gland within 24-48 hours. If there is no clinical improvement, surgical drainage may be required. It should be kept in mind that the presence of abscess may be demonstrated with USG in treatment-resistant cases (2). The most common complications except abscess formation are facial paralysis, salivary gland fistula, sialoadenitis and deep neck infection $(4,9)$. In our patient, acute suppurative parotitis completely resolved with 10 days of ampicillin treatment before these complications developed. 
In conclusion, if there is no history of contact with mumps in patients presenting with swelling and tenderness in the parotid artery during the neonatal period, the first thing that should come to mind is acute NSP. To confirm the diagnosis of suppurative parotitis, it should be kept in mind that it is sufficient to show pus drainage through the Stenson canal.

Informed Consent: The informed consent was given by the parents of the patient.

Peer-review: Externally peer-reviewed.

Author Contributions: Concept - MYÖ; Design - MYÖ; Supervision - EKÖ, MKA; Collection and/or Processing - OE; Analysis and/or Interpretation - MYÖ, EKÖ; Literature Review - MYÖ, MKA; Writing MYÖ; Critical Review - EKÖ.

Conflict of Interest: The authors have not reported a conflict of interest.

Financial Disclosure: There is no financial support in this study.

\section{References}

1. Sabatino G, Verrotti A, de Martino M, Fusilli P, Pallotta R, Chiarelli $F$. Neonatal suppurative parotitis: a study of five cases. Eur J Pediatr 2009;158:312-4.

2. Spiegel $R$, Miron D, Sakran $V$, Horowitz $Y$. Acute neonatal suppurative parotitis: case reports and review. Pediatr Infect Dis $J$ 2004;23:76-8.

3. Schwab J, Baroody F. Neonatal suppurative parotitis: a case report. Clin Pediatr (Phila) 2003:42:565-6.

4. Decembrino L, Ruffinazzi G, Russo F, Manzoni F, Stronati M. Monolateral suppurative parotitis in a neonate and review of literature. Int J Pediatr Otorhinolaryngol 2012;76:930-3.

5. Velkoski A, Amoroso S, Brovedani P, Cont G, Trappan A, Travan L. Presentation of acute suppurative parotitis in a newborn with incessant crying. Arch Dis Child Fetal Neonatal Ed 2017;102:F125.

6. Skude G. Sources of the serum isoamylases and their normal range of variation with age. Scand J Gastroenterol 1975;10:577-84.

7. Coban A, Ince $Z$, Ucsel $R$, Ozgeneci A, Can G. Neonatal suppurative parotitis: a vanishing disease? Eur J Pediatr 1993;152:1004-5.

8. Ozdemir H, Karbuz A, Çiftçi E, Fitoz S, Ince E, Doğru U. Acute neonatal suppurative parotitis: a case report and review of the literature. Int J Infect Dis 2011;15:500-2.

9. Stong BC, Sipp JA, Sobol SE. Pediatric parotitis: a 5-year review at a tertiary care pediatric institution. Int J Pediatr Otorhinolaryngol 2006;70:541-4. 